\title{
Revaluation of agri-food waste to obtain bioethanol
}

\author{
Valerio-Cárdenas, Cintya ${ }^{1}$; De la Cruz-Burelo, Patricia $^{1}$; Guerrero-Zárate, David ${ }^{2}$; Montejo-García, Zaritma Y. ${ }^{2}$ \\ ${ }^{1}$ Universidad Popular de la Chontalpa. Carretera Cárdenas-Huimanguillo Km 2, Ranchería Paso y Playa, \\ 86597, Cárdenas, Tabasco, México. \\ ${ }^{2}$ Universidad Juárez Autónoma de Tabasco. Avenida Universidad S/N, Zona de la Cultura, Col. Magisterial, \\ Villahermosa, Centro, Tabasco, México. \\ *Corresponding author: cintya.valerio@upch.mx
}

Citation: Valerio-Cárdenas, C., De la Cruz-Burelo, P., Guerrero-Zárate, D. \& Montejo-García, Z. Y. (2021). Revaluation of agri-food waste to obtain bioethanol. Agro Productividad, 14(\#). https://doi.org/10.32854/ agrop.v14i7.1920

Editor in Chief: Dr. Jorge Cadena Iñiguez

Estimated publication date: August 2021

This work is licensed under a Creative Commons Attribution-Non-Commercial 4.0 International license.

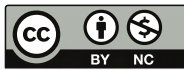

\begin{abstract}
Objective: Produce bioethanol from the alcoholic fermentation of agri-food waste.

Design/methodology/approach: food waste was collected for one month and separated into fruit and legumes waste; its size was reduced and then washed with hot acetone. A batch of $100 \mathrm{~g}$ of residue underwent acid hydrolysis with $5 \% \mathrm{H}_{2} \mathrm{SO}_{4}$ at $125^{\circ} \mathrm{C}$, the hydrolysate was fermented with Saccharomyces cerevisiae at $30{ }^{\circ} \mathrm{C}$ for $48 \mathrm{~h}$; the ferment was then distilled at $78^{\circ} \mathrm{C}$. The sugar content was determined following the phenolsulfuric method. Brix degrees, density and percentage w/w ethanol were measured with a densimeter.

Results: from the fruit residues, an organic fraction was obtained with a total sugar content of $53.3 \mathrm{~g} / 100 \mathrm{~g}$ of residue and $9.6^{\circ}$ Brix, generating $45 \mathrm{~mL}$ of distillate with $3.8 \% \mathrm{w} / \mathrm{w}$ of bioethanol. From the legumes residues, an organic fraction was obtained with a total sugar content of $19.4 \mathrm{~g}$ and $4.140^{\circ}$ Brix, generating $30 \mathrm{~mL}$ of distillate with $2.54 \% \mathrm{w} / \mathrm{w}$ of bioethanol.

Study limitations/implications: Rapid decomposition of waste due to bacterial and fungal decomposition complicates long-term storage.

Findings/conclusions: fermentable sugars can be obtained from the evaluated agri-food waste to obtain bioethanol. In this way, they can be integrated into the value chain as raw materials, reducing their accumulation and the environmental impact generated by their final disposal.
\end{abstract}

Keywords: Agri-food waste, bioethanol, fermentation, waste recovery.

\section{INTRODUCTION}

Currently, in several countries of the European Union, as well as in the United States, Argentina, Brazil and Colombia, the use of gasoline with a 5 to $10 \%$ bioethanol percentage is authorized, to reduce greenhouse gases emission, a commitment established by the international community in the Kyoto Protocol on climate change. Mexico joined this initiative (Carrillo-Nieves et al., 2019), in the Diario Oficial de la Federación (Official Journal of the Federation) issued the Norma Oficial Mexicana (Mexican Official Standard) NOM-016-CRE-2016, which states that "a maximum content of 5.8\% by volume of anhydrous ethanol is allowed as an oxygenate in Regular and Premium gasoline". 
Bioethanol is used both as an antiknock additive and to obtain ETBE (ethyl tertiary butyl ester), a substitute compound for MTBE (methyl tertiary butyl ester), which is a powerful carcinogen (Sanchez \& Cardona, 2008). In the immediate future, the bioethanol demand will increase, so raw materials availability will play an important role. The most used crops for bioethanol production are sugar cane, corn, wheat and rice (Zaldivar et al., 2001). Other proposed options are lignocellulosic wastes (Malagón et al., 2017; Rastogi \& Shrivastava, 2017) within which are wood, agricultural, agro-industrial and agri-food wastes. These residues are composed of cellulose (35-50\%), hemicellulose (15-25\%) and lignin (20-25\%) with the latter component being the only one that does not contain carbohydrates. Lignin, while providing structural strength to plants, protects them against pathogen and insect invasion (Zhao et al., 2012). For bioethanol production, it is necessary to remove lignin, as it acts as a barrier preventing the penetration of the acid responsible for converting cellulose and hemicellulose into reduced sugars (Alvarez-Castillo, 2012), which, through the fermentation process are converted into ethanol, $\mathrm{CO}_{2}$ and ATP molecules. Therefore, in the case of lignocellulosic waste, prior treatment is required to hydrolyze the lignin before obtaining bioethanol.

Thus, the process for obtaining bioethanol from lignocellulosic waste consists of four steps: pretreatment, hydrolysis, fermentation and distillation (Aditiya et al., 2016). Although technological improvements are needed to develop from these residues, their use would have the advantage of being accessible, renewable and low-cost. In addition, it contributes to the reduction of waste accumulation in the environment, since there is no management for its final disposal these end up in open dumps. In this sense, Martínez and Montoya (2013) report obtaining $0.5 \mathrm{~g}$ of bioethanol per gram of glucose obtained from a mixture of urban solid waste. Other authors such as Malagón et al. (2017) evaluated the bioethanol production from waste generated from fruit pulp from lemon, lulo, passion fruit, blackberry and mango production industry, and reported an average yield of $0.8 \mathrm{~g}$ bioethanol per $\mathrm{g}$ of glucose obtained from each sample and a mixture of them. Considering the accumulation of untreated agro-food waste at the Universidad Popular de la Chontalpa, this research developed a procedure to minimize the environmental impact they generate, using them as raw materials for bioethanol production.

\section{MATERIALS AND METHODS}

Agro-food wastes were collected at the Universidad Popular de la Chontalpa. The samples were defined among the collected residues and two materials were established from them: fruit residues, formed by a mixture of fruit peels (banana, papaya, melon, watermelon and pineapple) and legumes residues, formed by a mixture of vegetables (onions, cabbages, potatoes, carrots and lettuce).

\section{Physical and chemical pre-treatment}

A $100 \mathrm{~g}$ of the biomass to be assessed was weighed and cut into pieces until reduced to a $\pm 3 \mathrm{~cm}$ size. Subsequently, they were immersed in acetone and heated to a boiling point for $10 \mathrm{~min}$ in constant agitation. They were then filtered and dried at room temperature $\left(24^{\circ} \mathrm{C} \pm 2\right)$. 


\section{Bioethanol obtention}

Acid hydrolysis: the dry mixtures were placed in glass reagent bottles and a 5\% solution of $\mathrm{H}_{2} \mathrm{SO}_{4}$ was added to them. The bottles were placed in a pressure cooker and heated at $115^{\circ} \mathrm{C}$ for $20 \mathrm{~min}$. The resulting juice was then pressed to obtain an organic fraction containing fermentable sugars.

Fermentation: $50 \mathrm{~mL}$ of the hydrolysate was fermented with $3 \mathrm{~g}$ of the yeast (Saccharomyces cerevisiae) at $30^{\circ} \mathrm{C}$ for $48 \mathrm{~h}$.

Distillation: the ferment was distilled at $78{ }^{\circ} \mathrm{C}$, separating the head and tail of the distillate.

\section{Quantification of reducing sugars by the Dubois method}

A calibration curve was defined using glucose standard solutions (Table 1). For the analysis of the samples, $1 \mathrm{~mL}$ of $5 \%$ phenol and $3 \mathrm{~mL}$ of $\mathrm{H}_{2} \mathrm{SO}_{4}$ were added to $1 \mathrm{~mL}$ of the hydrolysate. The absorbance assessment was performed at $504 \mathrm{~nm}$ with a dilution factor of 2 in an Evolution 300 UV-Vis Thermo Scientific spectrophotometer (Dubois et al., 1956).

\section{Calculation to determine total sugars}

The following equation was used to calculate the grams of total sugars (HernándezGalindo, 2017):

$$
\frac{g \text { sugar }}{100 g \text { dry residue }} \equiv \frac{A b s^{*} R * F}{1000} * \frac{1 L}{1000 m L} * \frac{V f}{P o} * \frac{100 g \text { fresh residue }}{X g \text { dry residue }} * 100
$$

Where:

Abs: measured absorbance

$R$ : value of the calibration line

$F$ : dilution factor

$V f$ : final volume of hydrolysate

$P o$ : initial weight of the substrate

$X$ : percentage of real dry residue

Table 1. Standard glucose concentrations.

\begin{tabular}{c|c|c|c|c}
\hline Tube & $\mathbf{H}_{\mathbf{2}} \mathbf{O}(\mathbf{m L})$ & glucose $(\mathbf{m L})$ & phenol $(\mathbf{m L})$ & $\mathbf{H}_{\mathbf{2}} \mathbf{S O}_{\mathbf{4}}(\mathbf{m L})$ \\
\hline 1 & 1 & 0 & 1 & 3 \\
\hline 2 & 0.9 & 0.1 & 1 & 3 \\
\hline 3 & 0.8 & 0.2 & 1 & 3 \\
\hline 4 & 0.7 & 0.3 & 1 & 3 \\
\hline 5 & 0.5 & 0.5 & 1 & 3 \\
\hline 6 & 0.4 & 0.6 & 1 & 3 \\
\hline 7 & 0.2 & 0.8 & 1 & 3 \\
\hline 8 & 0.1 & 0.9 & 1 & 3 \\
\hline 9 & 0 & 1 & 1 & 3 \\
\hline
\end{tabular}




\section{Brix determination}

$4 \mathrm{~mL}$ of hydrolyzed juice were injected into a densitymeter model Density Meter Anton Paar DMA 4100 M.

w/w of bioethanol (\%)

$4 \mathrm{~mL}$ of bioethanol were injected into a densitymeter model Anton Paar DMA $4100 \mathrm{M}$ under ISO 5725 OIML-ITS-90.

\section{RESULTS AND DISGUSSION}

The obtention of bioethanol began with the recollection of agro-food waste produced at the university cafeterias. Plastic containers with lids were used for this purpose, which indicated not to mix organic waste with other types of waste, such as paper, plastic, aluminum or meat waste. The waste was collected daily and transported to the Sustainable Chemistry Laboratory for treatment.

Table 2 shows the quantification of the waste collected for one month $(80.2 \mathrm{~kg})$. This estimate indicates that, at the Universidad Popular de la Chontalpa, an average of $20 \mathrm{~kg}$ per week are generated. During a year it is possible that approximately $1 \mathrm{t}$ of agro-food waste could be generated, which, if not treated, is taken to the sanitary landfill in the municipality of Cárdenas, Tabasco, Mexico.

Once the samples were collected, they were grouped into fruit or legumes residues and immediately underwent mechanical and chemical pretreatment with acetone (Figure 2). This pretreatment has two main purposes. First, to hydrolyze the lignins which, as already mentioned, hinders the present reducing sugars released of the biomass. Second, to dehydrate the samples, to avoid their decomposition by bacterial or fungal growth. It is important to note that the solvent used in this step is recovered by filtration and can be reused (after distillation) with another batch of biomass. This minimizes the generation of polluting chemical residues.

The next step consists of hydrolysis of the sample to generate the reducing sugars from cellulose and hemicellulose. Figure 3 shows the assessment of the organic fractions obtained from the waste mixtures by acid hydrolysis. The obtained value was used to calculate the number of total sugars per $100 \mathrm{~g}$ of dry residue. A value of $53.3 \mathrm{~g}$ from the fruit mixture was obtained, a high value, because in addition to glucose it contains sucrose and fructose; a value of $19.4 \mathrm{~g}$ was obtained from the legumes mixture.

Table 2. Total quantification of agri-food waste generated in the university restaurants.

\begin{tabular}{c|c|c|c|c|c|c}
\hline Week & $\begin{array}{c}\text { day 1 } \\
(\mathbf{k g})\end{array}$ & $\begin{array}{c}\text { day 2 } \\
(\mathbf{k g})\end{array}$ & $\begin{array}{c}\text { day } \mathbf{3} \\
(\mathbf{k g})\end{array}$ & $\begin{array}{c}\text { day } \mathbf{4} \\
(\mathbf{k g})\end{array}$ & $\begin{array}{c}\text { day } \mathbf{5} \\
(\mathbf{k g})\end{array}$ & $\begin{array}{c}\text { Total quantification } \\
\text { of residues }(\mathbf{k g})\end{array}$ \\
\hline 1 & 3.3 & 5.1 & 4.3 & 3.5 & 3.0 & 19.2 \\
\hline 2 & 5.5 & 3.0 & 4.1 & 3.7 & 3.8 & 20.1 \\
\hline 3 & 5.0 & 4.5 & 3.4 & 4.0 & 3.1 & 20 \\
\hline 4 & 5.0 & 4.3 & 4.5 & 3.3 & 3.8 & 20.9 \\
\hline Total & \multicolumn{7}{|l}{} \\
\hline
\end{tabular}




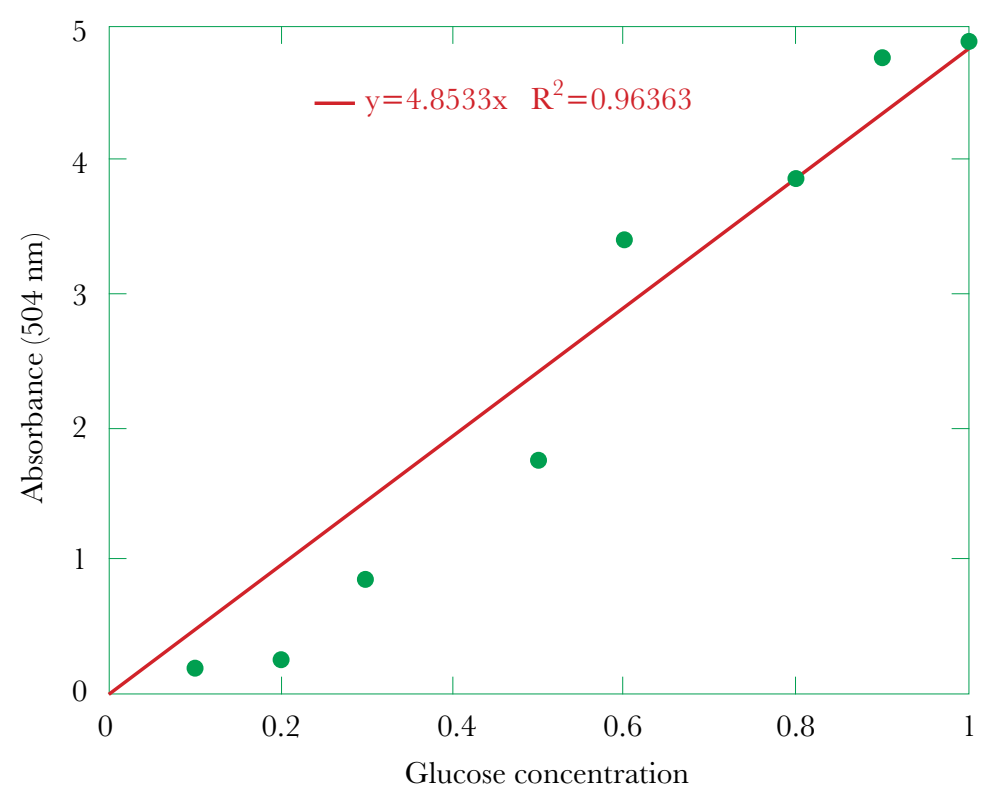

Figure 1. Calibration curve for the glucose concentration determination.

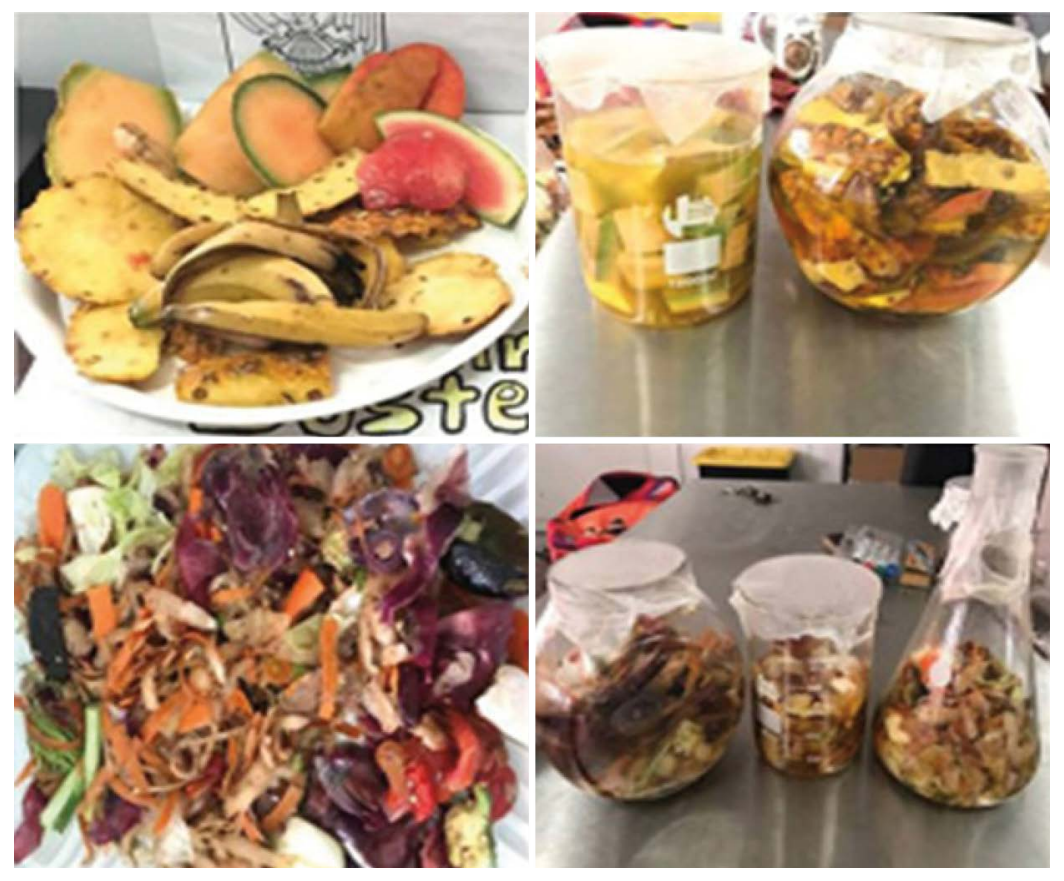

Figure 2. Mechanical and chemical treatment of agri-food waste.

Table 3 shows the characteristics of the obtained organic fractions from each of the mixtures after treatment with acid hydrolysis. The density value for the fruit mixture was $1.03 \mathrm{~g} / \mathrm{mL}$ and $9.86^{\circ} \mathrm{Brix}$, values close to those reported for mandarin peel hydrolysates $1.15 \mathrm{~g} / \mathrm{mL}$ and $14^{\circ}$ Brix (Llenque-Díaz et al., 2020). A hydrolysate with a $1.0144 \mathrm{~g} / \mathrm{mL}$ density and $4.140^{\circ}$ Brix was obtained from the legumes mixture. Brix degrees are the percentage of soluble solids present in some substances. For fruits, the value indicates the 
amount of present sugar (sucrose), which explains the higher value obtained from the fruit peel mixture compared to the hydrolyzate of the legumes mixture.

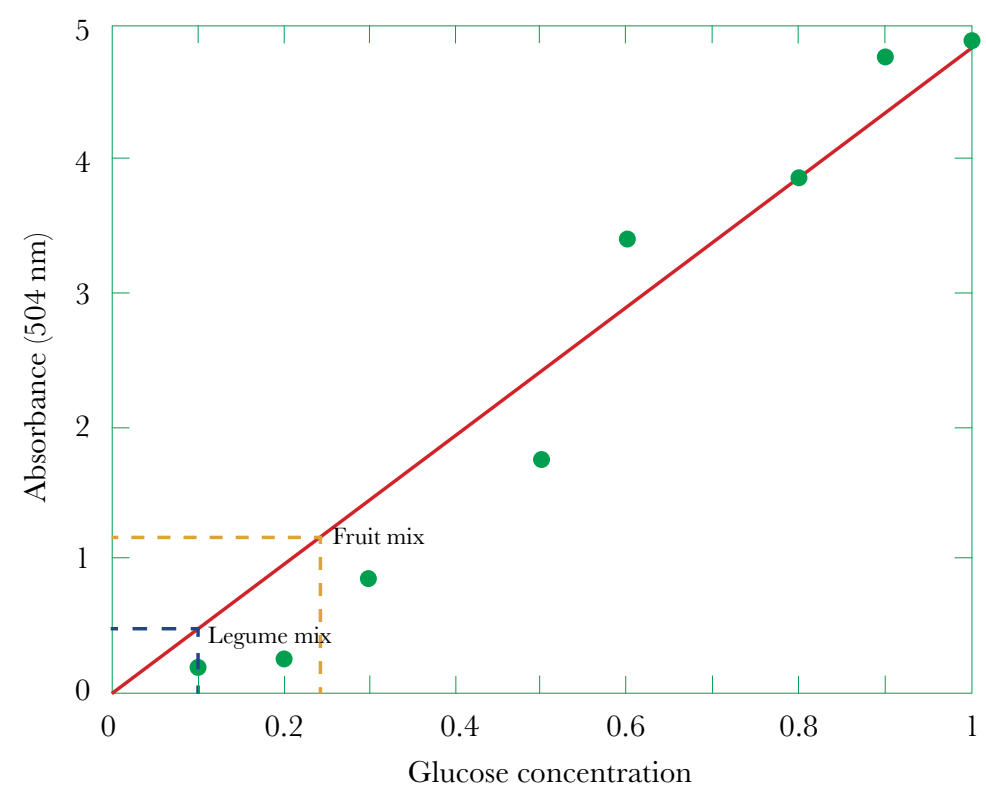

Figure 3. Determination of the amount of glucose in hydrolyzed samples.

Table 3. Characteristics of hydrolyzed organic fractions.

\begin{tabular}{c|c|c}
\hline Characteristics & Fruit mix & Legume mix \\
\hline Density $(\mathrm{g} / \mathrm{ml})$ & 1.03 & 1.01 \\
\hline${ }^{\circ}$ Brix & 9.86 & 4.14 \\
\hline
\end{tabular}

Table 4 shows the bioethanol yields obtained from the evaluated blends. From the fruit peel blend, a yield of $3.8 \% \mathrm{w} / \mathrm{w}$ of bioethanol was obtained per $45 \mathrm{~mL}$ of distillate; while, for the legumes blend, a yield of $2.5 \% \mathrm{w} / \mathrm{w}$ of bioethanol was obtained per $30 \mathrm{~mL}$ of distillate under the same test conditions (Figure 4). Values close to those reported by Llenque-Díaz et al. (2020), where they obtained $3.8 \%(\mathrm{v} / \mathrm{v})$ for mandarin peel and $4.2 \%(\mathrm{v} / \mathrm{v})$ for passion fruit peel per $100 \mathrm{~mL}$ of distilled ferment.

Table 4. Characteristics of distillates.

\begin{tabular}{c|c|c}
\hline Characteristics & Fruit mix & Legume mix \\
\hline Ethanol volumen $(\mathrm{mL})$ & 45 & 30 \\
\hline$\% \mathrm{w} / \mathrm{w}$ & 3.8 & 2.5 \\
\hline
\end{tabular}

\section{CONGLUSIONS}

Agro-food waste is accessible, low-cost and renewable, and represents a potential source for bioethanol production since it is made up of polysaccharides that can be converted into fuel through a standard chemical process. This study recorded moderate ethanol yield from discarded lignocellulosic material, integrating it into the value chain and contributing 
to a circular economy of the food industry. In this way, the amount of waste generated at the University, which is generally destined for inadequate final disposal, was reduced.

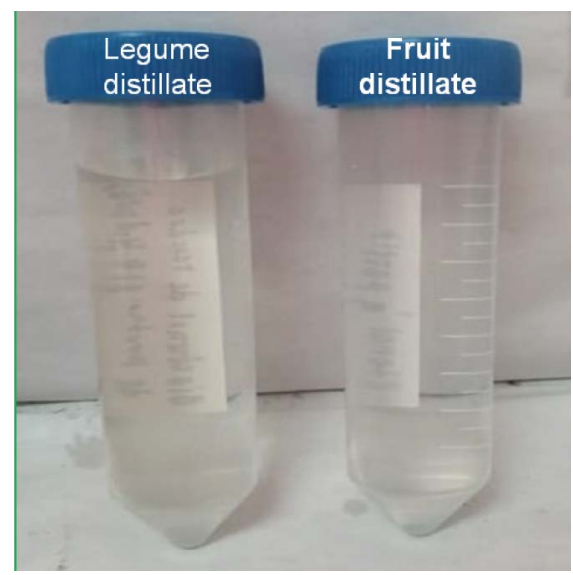

Figure 4. Distillates obtained from the agri-food waste.

\section{AGKNOWLEDGMENTS}

To Dr. Haydée Rojas Cabrera for her contributions to this work and her unconditional support.

\section{REFERENGES}

Aditiya, H.B., Mahlia, T.M.I., Chong, W.T., Nur, H., \& Sebayang, A.H. (2016). Second generation bioethanol production: a critical review. Renewable and Sustainable Energy Reviewes 66: 631-653. doi:10.1016/j.rser.2016.07.015.

Alvarez-Castillo, A., Salgado-Delgado, R., García-Hernández, E., Domínguez- Domínguez, M.M., Granandos-Baeza, J.M., AguirreCruz, A., Carmona-García, R., Morales- Cepeda, A., Herrera-Franco, P.J., Licea-Claveríe, A., \& Mendoza-Martínez, A.M. (2012). Aprovechamiento integral de los materiales lignocelulósicos. Revista Iberoamericana de Polimeros 13(4):140-150.

Carrillo-Nieves, D., Rostro-Alanís, M.J., de la Cruz-Quiroz, R., Ruiz, J.A., Iqbal, H.M.N., \& Parra-Saldívar, R. (2019). Current status and future trends of bioethanol production from agroindustrial wastes in Mexico. Renewable and Sustainable Energy Reviewes 102: 63-74. doi:10.1016/j. rser.2018.11.03.

Diario Oficial de la Federación https://www.dof.gob.mx/nota_detalle.php?codigo=5450011\&fecha=29/08/20

Dubois, M., Gilles, K.A., Hamilton, K. J., Rebers, P.A. \& Smith, F. (1956). Colorimetric Method of Determination of sugars and Related Substances. Analytical Chemistry 28(3): 350-356.

Hernánde-Galindo, G. (2017). Obtención de bioethanol a partir de hidrolizados de residuos de fruta. Tesis de Maestria. Universidad de Oviedo.

Llenque-Díaz, L.A., Quintana-Díaz, A., Torres-Lino, L., \& Segura-Vega, R. (2020). Bioethanol production from organic plant waste. Revista de Investigación Cientifica REBIOL 40(1): 21-29. doi:10.17268/rebiol.2020.40.01.03.

Malagón-Micán, M.L., Paéz, A.I., Lache-Muñoz, A., Santos-Aguilar, J., \& Zabala-García, D.A. (2017). Producción de bioetanol a partir de diferentes mezclas de los residuos orgánicos generados en una empresa alimentos. Revista de Investigación 10: 47-59. doi:10.29097/issn.201 1639x.

Rastogi, M., \& Shrivastava, S. (2017). Recent adavances in second generation bioetanol production: An insight to pretreatment, saccharification and fermentation processes. Renewable and Sustainable Energy Reviews 80: 330-340. doi:10.1016/j.rser.2017.05.225.

Sánchez, O.J., \& Cardona, C.A. (2008). Trends in biotechnological production of fuel etanol from different feedstocks. Bioresource Technology 99: 5270-5295. doi:10.1016/j.biortech.2007.11.013.

Zhao, X., Zhang, L., \& Liu, D. (2012). Biomass recalcitrance. Part I: the chemical compositions and physical structures affecting the enzymatic hydrolysis of lignocellulose. Biofuels. Bioprod Bioref 6:465-482. doi:10.1002/bbb.1331. 